脊髄外科研究に用いられる

スコアリングシステムおよびその特徴(2)

腰椎疾患の評価システム

\section{An Overview of Clinical Scoring Systems Applicable for Lumbar Spine Surgery}

\author{
金 景 成*1 井須豊 彦*2 \\ ${ }^{* 1}$ 日本医科大学千葉北総病院脳神経センター \\ $* 2$ 釧路労災病院脳神経外科
}

Key words : lumbar spine scoring JOA score ODI $\mathrm{RDQ}$

\section{1. はじめに}

世界各地で行われている腰椎疾患に対する治療を同じ 尺度で評価することは, 治療法の開発や発展に寄与す る。脊椎疾患によって起こるしびれや痛み，麻痺などを それぞれ別々に評価することも時に有用であるが，変性 疾患である脊椎疾患が日常生活へ与える影響を含めて評 価することで，疾患に伴う障害をより正確に評価でき る ${ }^{1)}$. 本稿では, 腰椎疾患の評価に用いられるスコアリ ングシステムについて紹介し，その特徴および注意点に ついて解説する。

\section{2. スコアリングシステムの基礎知識}

スコアリングシステム全般にいえることだが, 点数化 して評価するには，その症状を 1 点とするのか， 2 点と するのか, 点数の重さを均等にする必要がある.また, すでに使用されているスコアリングシステムであったと しても，言語や文化の違いが質問票へ与える影響なども 考慮する必要があり, スコアの翻訳は, 単に言語として 翻訳するだけでは不十分で, 文化に適合させたうえで正 当性を評価する必要がある2,3)。つまり, 現在われわれが 日常で使用できるスコアリングシステムは，すでに日本 語に翻訳されその信頼性や妥当性があらためて確認され たものであり, その際表現方法や記載方法を変更しない で用いるよう注意すべきである，そのため，われわれが 個人的に訳したり，つくったものはスコアリングシステ ムとはいえず，基本的には書式なども変更せずに用いる ベきである。

\section{3. 腰椎疾患に用いる評価法}

腰椎疾患による障害を評価するためには，(オーバー ラップする部分もあるが) (1)痛みの程度, (2)運動機能へ の影響, (3)QOLへの影響の3つについて検討する必要が ある。

\section{1 痛みの評価}

しびれ，痛みの程度をあえて数字などを用いて客観的 に評価するものであり，患者，医療者ともに簡便でわか りやすい利点があるが, しびれ, 痛みに対する個人的な 閾值の違いにより客観性にそしいことも欠点として考慮 する必要がある。

1 ) 数值化評価尺度 (numerical rating scale : NRS)

しびれ，痛みなどの強さを $0 \sim 10$ の整数で数值化する 評価法である。痛みに関してなら 0 :「痛みがない」, 10 ： 「想像できる最大の痛み」とした場合の痛みの強さを，患 者自身に口頭で回答させたり，○で囲んだりすることで 評価する. 口頭での回答が可能であるため, 臨床現場で 最も使いやすく，われわれも頻用している.

\section{2 ）視覚的評価尺度（visual analogue scale：VAS)}

NRS と同様に0〜10 までで症状の強さを数值化して評 価するが, 紙面上で行う点がNRS と異なる. 紙面上で横 棒線上の左端 $0 \mathrm{~cm}$ のころに「痛みがない」, 右端 $10 \mathrm{~cm}$ のところに「想像できる最大の痛み」と記載し, 患者自 身に症状の強さをその間の該当するところに印をつけさ せ，その場所の距離を症状の強さとして定量化する。一 般に $0 \mathrm{~cm}$ から $10.0 \mathrm{~cm}$ までを $\mathrm{mm}$ 単位 101 段階で評価す る. NRSより細かい評価ができるが, 紙面上で行うため

Kyongsong Kim, M.D. ${ }^{* 1}$, Toyohiko Isu, M.D. ${ }^{* 2}$

日本医科大学千葉北総病院脳神経センター / $270-1694$ 印西市鎌刈 1715 〔連絡先 : 金 景成〕

Address reprint requests to : Kyongsong Kim, M.D., Department of Neurosurgery, Chiba Hokuso Hospital, Nippon Medical School, 1715 Kamagari, Inzai-shi, Chiba 270-1694, Japan 
Table 1 Roland-Morris disability questionnaire ${ }^{2)}$

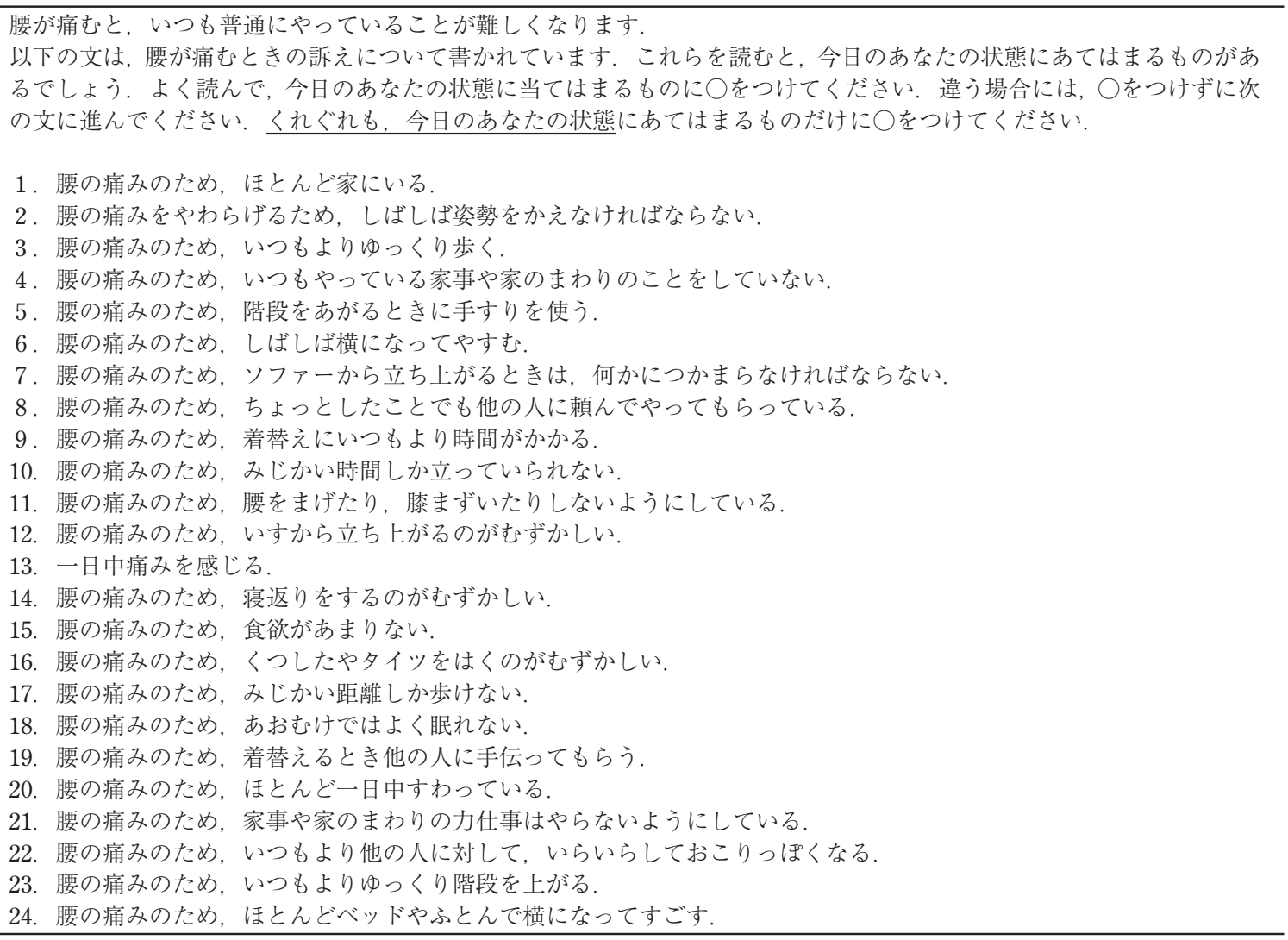

やや煩雑である。

\section{3）その他}

NRS をより簡便化し，4段階で評価する口頭式評価尺 度（verbal rating scale：VRS）や，笑顔から泣き顔まで の絵をみて 6 段階などで評価するフェイススケールなど も用いられるが，評価が扮扮まかになってしまい，経時 的変化も捉えがたい.

\section{2 運動機能への影響を評価（腰椎疾患に特異的な 評価法)}

1) Roland-Morris disability questionnaire (RMDQ) (Table 1)

RMDQ は最も広く使用されている腰痛特異的評価法 である ${ }^{4} .1983$ 年に発表された 24 の質問によって構成さ れた腰痛を評価するスコアリングシステムであり，2003 年に Fujiwara らによって日本語に翻訳され，日本語でも 使用可能である ${ }^{2,5)}$. 問題点としては, 身体機能に主眼が おかれているため，精神機能に関する質問を含んでいな いことや，2 択式であるためあてはまらない場合には回 答を選択できないこと, さらには「腰痛のため」という 言葉が多く使われていることから，腰痛がなく下肢痛の みの場合答えづらい点などが指摘されている ${ }^{21}$ ，そのた
め Patrick らが, modified version として,「腰痛のため」 という言葉を「腰もしくは下肢の問題で」と変更してい るが, これに対し Roland らは, 初期段階でこのような表 現を使わないことを推奨しているものの, 下肢痛で苦し んでいる場合は modified versionを使うことに関しても 許容している ${ }^{2,6)}$.

\section{2 ) Oswestry disability index (ODI) (Table 2)}

ODI は RMDQ に次いで広く使われている腰痛特異的 評価法である ${ }^{4)}$. ODI は 1980 年に発表後, 1989 年にv 2.0 へ変更され，その後 Fujiwara らによって日本語に翻訳さ れたため, 日本語でも使用可能である 2,7$)$. 腰痛によって 障害される日常生活動作 10 項目の質問に，0５の 6 段 階の中から 1 つを患者自身が直接選択する評洒法であ る，腰痛による社会的損失をより評価できる点や，腰痛 だけでなく下肢痛の影響も含んで抢り，術前後の下肢痛 とも相関すると報告されている点で優れている8 ${ }^{8)}$.一方, 性生活に関する質問が含まれるため回答率が低下するこ ともあり, 10 代の症例やがん転移の症例では省略される ことに注意が必要である7 .

ODI はRMDQ と相関関係にあるが, ODI でスコアが 高くなる傾向があり, 症状が重い場合では ODIで感受性 
以下のアンケートに答えてください。これらは腰の痛み（あるいは足の痛み）が，あなたと日常生活にどのように影響してるのかを知る ためのものです。すべてのアンケートに答えてください，それぞれの項目の中で，もっともあなたの状態に近いものを選んで，番号を○ でかこんでください.

1. 痛みの強さ

0. 今のところ, 痛みはまったくない

1.今のところ, 痛みはとても軽い

2. 今のところ, 中くらいの痛みがある

3. 今のところ, 痛みは強い

4. 今のところ, 痛みはとても強い

5.今のところ, 想像を絶するほどの痛みがある

2. 身の回りのこと（洗顔や着替えなど）

0 ，痛みなく，普通に身の回りのことができる

1. 身の回りのことは普通にできるが, 痛みがでる

2. 身の回りのことはひとりでできるが, 痛いので時間が かかる

3. 少し助けが必要だが, 身の回りのほとんどのことは, ど うにかひとりでできる

4.身の回りのほとんどのことを, 他のひとに助けても らっている

5．着替えも洗顔もできず，寝たきりである

3．物を持ち上げること

0 ．痛みなく，重いものを持ち上げることができる

1. 重いものを持ち上げられるが, 痛みがでる

2. 床にある重いものは痛くて持ち上げられないが,（テー ブルの上などにあり) 持ちやすくなっていれば, 重いも のでも持ち上げられる

3. 重いものは痛くて持ち上げられないが,（テーブルの上 などにあり）持ちやすくなっていれば，それほど重くな いものは持ち上げられる

4. 軽いものしか持ち上げられない

5. 何も持ち上げられないか, 持ち運びもできない

4.歩くこと

0.いくら歩いても痛くない

1. 痛みのため, $1 \mathrm{~km}$ 以上歩けない

2. 痛みのため, $500 \mathrm{~m}$ 以上歩けない

3. 痛みのため, $100 \mathrm{~m}$ 以上歩けない

4.つえや松葉づえなしでは歩けない

5.ほとんど床の中で過ごし, 歩けない

5. 座ること

0．どんないすにでも，好きなだけ座っていられる

1. 座りごこちの良いいすであれば, いつまでも座ってい られる

2. 痛みのため, 1 時間以上は座っていられない

3. 痛みのため, 30 分以上は座っていられない

4. 痛みのため, 10 分以上は座っていられない

5. 痛みのため, 座ることができない
6. 立っていること

0 ．痛みなく，好きなだけ立っていられる

1，痛みはあるが，好きなだけ立っていられる

2. 痛みのため, 1 時間以上は立っていられない

3. 痛みのため, 30 分以上は立っていられない

4. 痛みのため, 10 分以上は立っていられない

5 . 痛みのため, 立っていられない

7. 睡眠

0．痛くて目をさますことはない

1.ときどき, 痛くて目をさますことがある

2. 痛みのため, 6 時間以上はねむれない

3 . 痛みのため, 4 時間以上はねむれない

4. 痛みのため, 2 時間以上はねむれない

5. 痛みのため, ねむることができない

8．性生活（関係あれば）

0．性生活はいつもどおりで，痛みはない

1. 性生活はいつもどおりだが，痛みがでる

2. 性生活はほぼいつもど抒りだが，かなり痛む

3. 性生活は，痛みのためにかなり制限される

4. 性生活は, 痛みのためにほとんどない

5，性生活は，痛みのためにまったくない

9. 社会生活（仕事以外の付き合い）

0．社会生活はふつうで，痛みはない

1。社会生活はふつうだが，痛みが増す

2、スポーツなどのように，体を動かすようなものをのぞ けば，社会生活に大きな影響はない

3. 痛みのため社会生活は制限され，あまり外出しない

4. 痛みのため, 社会生活は家の中だけに限られる

5 . 痛みのため社会生活はない

10. 乗り物での移動

0 ，痛みなくどこへでも行ける

1. どこへでも行けるが，痛みがでる

2. 痛みはあるが, 2 時間程度なら乗り物に乗っていられる

3. 痛みのため, 1 時間以上は乗っていられない

4. 痛みのため, 30 分以上は乗っていられない

5 . 痛みのため, 病院へ行くとき以外は乗り物には乗らな w
が高く，腰痛による細かな障害については RMDQ で感 受性が高いとの指摘もあり，著者らは掠もにRMDQを 頻用している.

\section{3）日本整形外科学会腰痛疾患治療成績判定基準 (JOA スコア)（Table 3)}

JOA スコアは, 1986 年に報告された, 腰痛疾患に関す る自覚症状, 他覚所見, 日常生活動作, 膀胱機能の 4 群 で構成され，29 点満点で評価する ${ }^{9)}$. 各項目別に比較し 
Table 3 日本整形外科学会腰痛治療成績判定基準 (JOA スコア $)^{9)}$

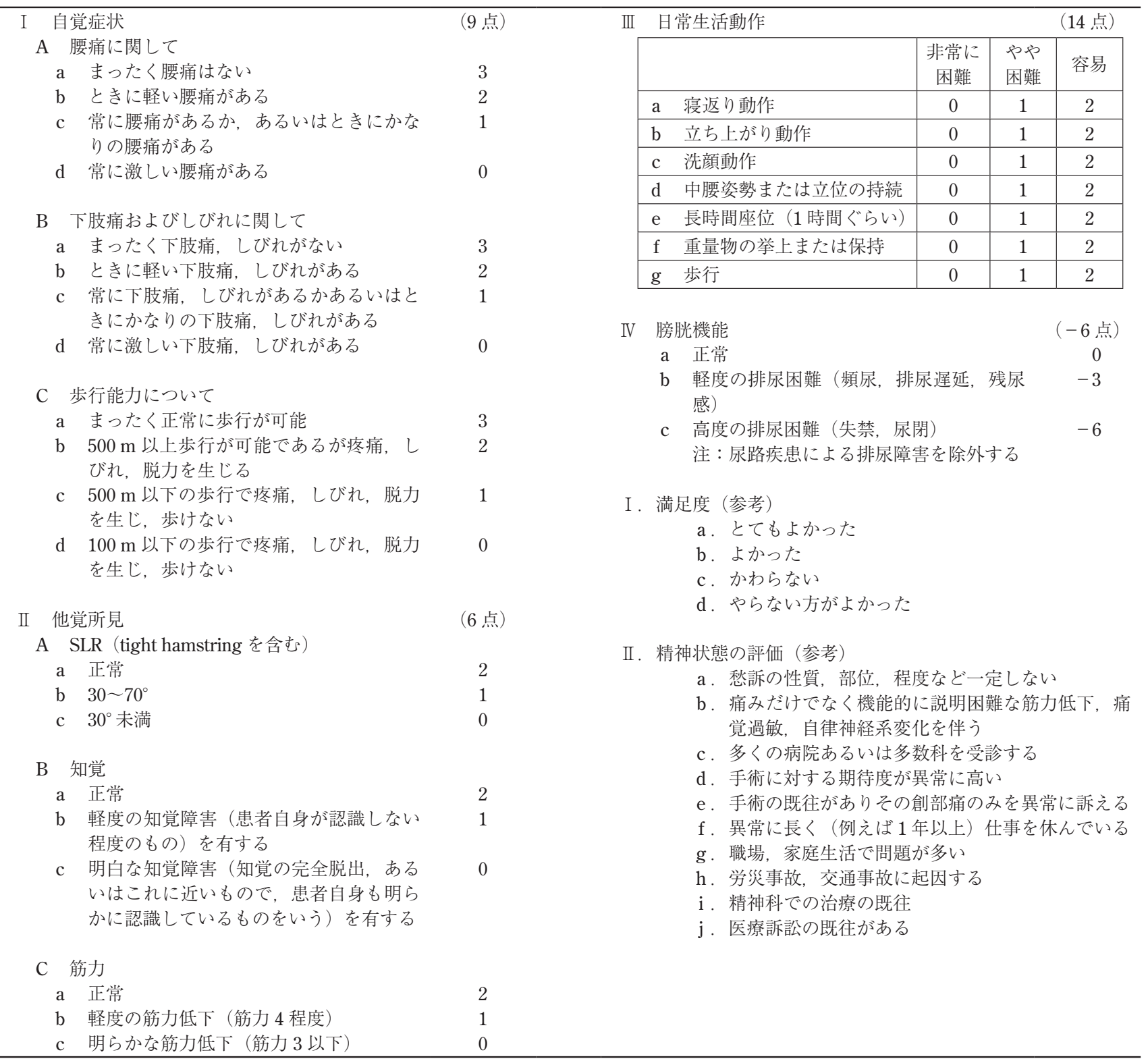

たり, 総合点で比較したりすることで, 腰痛疾患の重症 度判定や治療成績の評価に広く使用されており，JOA ス コアは ODI, RMDQ とともに SF-36 とすべてにおいて 相関があり, 特に SF-36の physical function と強く相関 していたとの報告 ${ }^{2)}$ もる一方，下肢の VAS としか相関 しなかったとの報告 ${ }^{8)}$ や, SF-36の身体機能, 痛みのみ で中等度の相関があったとする報告 ${ }^{10)}$ などさまざまな評 価がなされている.

一方, JOA スコアは医療者側が点数をつけることによ る正確性の問題や2），身体機能しか含まれず，心理社会 的評価を反映していない点8), さらには各評価項目およ び割り当てられた点数の妥当性が検証されていない点な
どが挙げられている。そのため，JOAスコアとともに SF-36 や ODI，VAS などを計測したり ${ }^{8)}$, ODI や RMDQ のような患者自記式のスコアリングシステムをJOA ス コアへ含めることを推奨する報告が散見される2).

\section{4 ) Japanese Orthopaedic Association back pain evaluation questionnaire (JOA-BPEQ)}

上記のような従来の JOA スコアの欠点を補うため, 日 本整形外科学会は 2007 年に SF-36 と RMDQ を合わせた 合計 60 のアイテムから評価に適切な 25 のアイテムを選 択し ${ }^{11)}$ ，その信頼性を確認したうえで，新たなJOA スコ アとして JOA-BPEQ を報告した ${ }^{12)}$ ＪOA-BPEQ は，疼 痛関連障害 (4 項目), 腰椎機能障害 (6 項目), 歩行機能 


$$
\text { チューリヒ跛行質問票 }
$$

最近 1 ヶ月の状態について回答して下さい。

痛みは平均してどの程度でしたか？（腰やおしりの痛み、またそこから脚にまで及ぶ痛みを含みます。）

$\begin{array}{ccccc}\text { 痛みは全く } & \text { 弱い痛み } & \text { 中程度の痛み } & \text { 強い痛み } & \text { 非常に強い痛み } \\ \text { なかった } & \text { であった } \square & \text { であった } \square & \text { であった } \square & \text { であった }\end{array}$

どの位の頻度で腰、おしり、あるいは脚の痛みがありましたか?

1 週間に 1 回未満

1 週間に少なくとも 1 回

少なくとも 1 日 1 回

1 日の大半

四六時中痛みがある

腰あるいはおしりの痛みはどうでしたか？

$\begin{array}{ccccc}\text { 痛みは全く } & \text { 弱い痛み } & \text { 中程度の痛み } & \text { 強い痛み } & \text { 非常に強い痛み } \\ \text { なかった } & \text { であった } & \text { であった } & \text { であった } \square & \text { であった }\end{array}$

脚や足部の痛みはどうでしたか?

$\begin{array}{ccccc}\text { 痛みは全く } & \text { 弱い痛み } & \text { 中程度の痛み } & \text { 強い痛み } & \text { 非常に強い痛み } \\ \text { なかった } & \text { であった } & \text { であった } & \text { であった } \square & \text { であった }\end{array}$

脚や足部のしびれやうずきはどうでしたか？

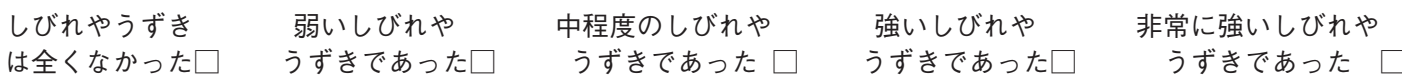

脚や足部の衰え具合はどうでしたか?

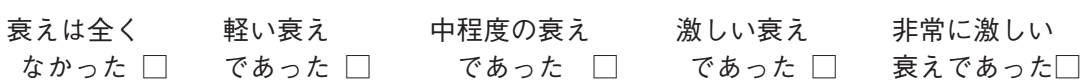

バランス（安定感）に問題はありましたか？

いいえ、バランスをとることに全く問題はなかった

はい、バランスを崩したり足元がしっかりしていなかったりすると、ときどき感じた

はい、バランスを崩したり足元がしっかりしていなかったりすると、しばしば感じた

Fig. 1 Swiss spinal stenosis questionnaire 日本語版 ${ }^{15)}$

重症度に関する質問が $7 つ$, 身体機能に関する質問が $5 つ$, 満足度に関する質問が 6 つの全 18 項目，回答に対しそれぞれ 1 から 4 または 5 までの点数をつける.（次頁に続く）

障害 (5 項目), 社会生活障害 (3 項目), 心理的障害 (7 項目)の 5 種類 25 の質問からなる患者自記式のスコアリ ングシステムで, 結果の解析は, 各因子内の設問に統計 学的に選定した整数の係数をかけて合計数を計算し, そ れぞれ独立のものとして評価する。具体的には，スコア をエクセルを用いた専用計算ソフトを用いて算出し， 5 つの各因子について 100 点満点で評価する。

5 ) Swiss spinal stenosis questionnaire (別名 Zurich claudication questionnaire) (Fig. 1)

腰部脊柱管狭窄症に関する自記式簡易評価法であり, 妥当性や信頼性に優れているというエビデンスを獲得し ている ${ }^{13,14)} .2010$ 年に原ら ${ }^{15)}$ によって日本語版が公開さ

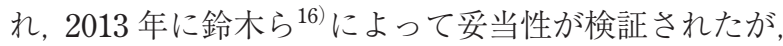
日本語で用いるには，さらなる信頼性や妥当性に関する 検討が必要であろう。

\section{QOL への影響の評価}

腰椎疾患に伴うさまざまな症状は, 睡眠障害や意欲低 下，不安，抑うつ傾向，食欲不振などへ影響するため， それらが実際の日常生活へどの程度影響しているのかも 評価する必要がある. SF-36 は，健康関連 QOLを測定す るための科学的な信頼性・妥当性をもつ健康状態を評価 する尺度であり，さまざまな疾患の研究や，さまざまな 評価法を評価する尺度としても用いられているが2,5,8), 前号にて安田 ${ }^{17)}$ がすでに解説しているため, 本稿では省 
最近 1 ヶ月における平均的な 1 日について考えて下さい。

どの位の距離を歩くことができましたか？

3 キロメートル以上

数百メートル以上、 3 キロ末満

15 メートル以上、数百メートル未満

15 メートル未満

戸外やショッピングセンター内を散歩したりしましたか？

はい、痛みがなく楽に歩けた

はい、しかし時々痛みがあった

はい、しかし痛みが常にあった

いいえ、歩けなかった

食料品・日用品やその他の物などの買い物に出かけましたか？

はい、痛みがなく楽に出かけられた

はい、しかし時々痛みがあった

はい、しかし痛みが常にあった

いいえ、出かけられなかった

家の中を他の部屋に行ったりして歩きましたか？

はい、痛みがなく楽に歩けた

はい、しかし時々痛みがあった

はい、しかし痛みが常にあった

いいえ、歩けなかった

寝室からトイレまで歩きましたか？

はい、痛みがなく楽に歩けた

はい、しかし時々痛みがあった

はい、しかし痛みが常にあった

いいえ、歩けなかった
以下のことがらについて、どの程度満足していますか？

全体的に考えて、腰の手術結果に満足していますか？

非常に満足

やや満足

やや不満足

非常に不満足

手術後、痛みの軽減に満足していますか?

非常に満足

やや満足

やや不満足

非常に不満足

手術後、歩行能力に満足していますか？

非常に満足

やや満足

やや不満足

非常に不満足

手術後、家事や庭仕事、仕事の出来具合に満足していますか？

非常に満足

やや満足

やや不満足

非常に不満足

太ももや脚、足部の力強さに満足していますか？

非常に満足

やや満足

やや不満足

非常に不満足

バランス、または立った時の安定感に満足していますか？

非常に満足

やや満足

やや不満足

非常に不満足

Fig. 1 続き

略する。注意点としては, 対象年齢が 16 歳以上である点 や，標準性を保つためレイアウトや文章表現の変更が禁 じられている点などである。

\section{4 心理社会的因子の評価}

\section{Brief scale for evaluation of psychiatric problems in} orthopedic patients (BS-POP) (Fig. 2)

心理・社会的因子は，腰椎疾患患者における治療成績 や患者満足度の低下に影響することが知られてい $る^{18,19)}$ 。 心理・社会的因子の評価方法として開発された BS-POP はこのような患者背景の評価に有用である ${ }^{20)}$. 患者の自己評価用のものと, 治療者側が患者を評価する ものとが別にあり，前者には抑うつ，イライラ感などに 関する質問が 10 項目，後者には診察における患者自身の 問題などに関する 8 項目があり，それぞれに 3 段階で評
価する。医師用 11 点以上，もしくは医師用 10 点以上か つ患者用 15 点以上の場合には精神医学的関与が疑われ る.

\section{4. スコア使用に関する文献レビュー}

腰下肢痛に対して ODI や SF-36 を別に検討する必要 があるのかどうかについては議論もあるが, DeVine $ら^{21)}$ は腰痛に関する研究において VAS と ODI, SF-36が 中等度の相関にとどまったことから，それぞれ別々に評 価することを勧めている。また，腰椎術後の症状と治療 満足度を比較した検討によると，治療満足度は歩行距離 の改善との相関は低く，疼痛レベルの影響を受けやす く22)，各種スコアは自制内である痛みと相関することも 指摘されており ${ }^{23)}$ ，やはり腰下肢痛を NRSなどで評価す 
闺師に対する質問項目

\begin{tabular}{|c|c|c|c|}
\hline 質問項目 & \multicolumn{3}{|c|}{ 回答と点数 } \\
\hline (1) 痛みのとぎれることはない & 1. そんなことはない & 2. 時々とぎれる & 3. ほとんどいつも痛む \\
\hline (2) 患部の示し方に特徵がある & 1. そんなことはない & 2. 患部をさする & $\begin{array}{l}\text { 3. 指示がないのに衣服を } \\
\text { 脱ぎ始めて患部を見せる }\end{array}$ \\
\hline (3) 患肢全体が痛む(しびれる) & 1. そんなことはない & 2. 時々 & 3. ほとんどいつも \\
\hline $\begin{array}{l}\text { (4) 検査や治療をすすめられたとき、不機嫌、 } \\
\text { 㛫的、または理屈っぽくなる } \\
\end{array}$ & 1. そんなことはない & 2. 少し拒否的 & 3. おおいに拒否的 \\
\hline (5) 知覚検査で刺激すると過剩に反応する & 1. そんなことはない & 2. 少し過剩 & 3. おおいに過剩 \\
\hline (6) 病状や手術について繰り返し質問する & 1. そんなことはない & 2. 時々 & 3. ほとんどいつも \\
\hline (7) 治療スタッフに対して、人を見て態度を変える & 1. そんなことはない & 2. 少し & 3. 著しい \\
\hline $\begin{array}{l}\text { (8) ちょつとした症状に、これさえなければと } \\
\text { こだわる }\end{array}$ & 1. そんなことはない & 2. 少しこだわる & 3. おおいにこだわる \\
\hline & & & 合計 \\
\hline
\end{tabular}

\begin{tabular}{|c|c|c|c|}
\hline 質問項目 & \multicolumn{3}{|c|}{ 回答と点数 } \\
\hline (1) 泣きたくなったり、泣いたりすることがありますか & 1. いいえ & 2. 時々 & 3. ほとんどいつも \\
\hline (2)いつもみじめで気持ちが浮かないですか & 1.いいえ & 2. 時々 & 3. ほとんどいつも \\
\hline (3)いつも緊張して、イライラしていますか & 1.いいえ & 2. 時々 & 3. ほとんどいつも \\
\hline (4) ちょっとしたことが瘷(しやく)にさわって腹が立ちますか & 1.いいえ & 2. 時々 & 3. ほとんどいつも \\
\hline (5) 食欲はふつうですか & 3.いいえ & 2. 時々なくなる & 1.ふつう \\
\hline (6) 1日のなかでは、朝方がいちばん気分がよいですか & 3. いいえ & 2. 時々 & 1. ほとんどいつも \\
\hline (7) 何となく疲れますか & 1.いいえ & 2. 時々 & 3. ほとんどいつも \\
\hline (8)いつもとかわりなく仕事ができますか & 3.いいえ & 2. 時々やれなくなる & 1. やれる \\
\hline (9) 睡眠に満足できますか & 3.いいえ & 2. 時々満足できない & 1. 満足できる \\
\hline (10) 痛み以外の理由で寝つきが悪いですか & 1.いいえ & 2. 時々寝つきが悪い & 3. ほとんどいつも \\
\hline
\end{tabular}

Fig. 2 BS-POP

ることは大切なようである22).

一方，上記のスコアを用いても，臨床的な悪化の閾值 を決定するのは難しいことも指摘されている. Gum ら ${ }^{24)}$ は 722 例の腰椎術後 1 年での状態を検討したところ，悪 化したと訴えた 107 例において，腰下肢の NRS，ODIな どは術前と比べて変化なく，術後症状に変化がないと答 えた 166 例においては，NRS および ODI が改善してい たことを報告している。

\section{5.おわりに}

腰椎疾患の評価に用いられるスコアリングシステムに ついて解説した。腰椎疾患に伴う症状については多面的 に評価する必要があるが，各スコアリングシステムの特 徵を理解したうえで適切に用いる必要がある。その際,
統計学的な数字の検討のみでは患者満足度の抽出が難し い点や，スコアリングシステムごとの改善や悪化の闇值 が決定されていない点などにも留意する必要がある.

一方，評価に用いられているさまざまな項目をみてみ ると，腰椎疾患で注目すべき症状や日常生活への影響に ついて知ることができ，参考にもなる，今後は，前号で 安田 ${ }^{17)}$ が指摘しているように，各スコアのカットオフ值 の検討がなされ，より臨床に即したスコアリングシステ ムの応用がなされることが期待される。

\section{文 献}

1）岩本直高：しびれ, 痛みの評価法. 井須豊彦, 金 景成編著： クリニカルスタッフのためのしびれ・痛み診療と薬物治療 東京, 中外医学社, 2014, pp40-48

2) Fujiwara A, Kobayashi N, Saiki K, et al : Association of the 
Japanese Orthopaedic Association score with the Oswestry Disability Index, Roland-Morris Disability Questionnaire, and short-form 36. Spine 28: 1601-1607, 2003

3）金 景成, 井須豊彦 : 脊䯣脊椎外科の Scoring (NCSS, JOA など)について，高安正和編：脳神経外科エキスパート脊髄・ 脊椎基本編．東京，中外医学社，2009, pp28-29

4）日本整形外科学会診療ガイドライン委員会, 腰痛診療ガイド ライン策定委員会：腰痛の治療評価法で有用なものは何か. 日本整形外科学会, 日本腰痛学会監: 腰痛診療ガイドライン 2012. 東京, 南江堂, 2012, pp64-66

5) Mousavi SJ, Parnianpour M, Mehdian $\mathrm{H}$, et al : The Oswestry Disability Index, the Roland-Morris Disability Questionnaire, and the Quebec Back Pain Disability Scale : translation and validation studies of the Iranian versions. Spine $31: \mathrm{E} 454^{-}$ 459, 2006

6) Patrick DL, Deyo RA, Atlas SJ, et al : Assessing health-related quality of life in patients with sciatica. Spine $20: 1899-1908$, 1995

7) Fairbank JC, Pynsent PB : The Oswestry Disability Index. Spine 25:2940-2952, 2000

8) Haro H, Maekawa S, Hamada Y : Prospective analysis of clinical evaluation and self-assessment by patients after decompression surgery for degenerative lumbar canal stenosis. Spine J $8: 380-384,2008$

9）井上駿一, 片岡 治, 田島 宝, 他: 腰痛疾患治療成績判定 基準委員会 (委員長 井上駿一). 日整会誌 60：905-911, 1986

10）田村睦弘, 松本守雄, 中村雅也, 他 : 腰椎変性疾患患者にお ける SF-36 を用いた QOL の評価. 臨床整形外科 39:781784,2004

11) Fukui M, Chiba K, Kawakami M, et al : JOA back pain evaluation questionnaire : initial report. J Orthop Sci 12:443-450, 2007

12) Fukui M, Chiba K, Kawakami M, et al : Japanese Orthopaedic Association Back Pain Evaluation Questionnaire. Part 2. Verification of its reliability: The Subcommittee on Low Back Pain and Cervical Myelopathy Evaluation of the Clinical Outcome Committee of the Japanese Orthopaedic Association. J Orthop Sci $12: 526-532,2007$

13) Stucki G, Daltroy L, Liang MH, et al : Measurement properties of a self administered outcome measure in lumbar spinal stenosis. Spine $21:$ 796-803, 1996
14) Tuli SK, Yerby SA, Katz JN : Methodological approaches to developing criteria for improvement in lumbar spinal stenosis surgery. Spine $31:$ 1276-1280, 2006

15）原 慶宏, 松平 浩, 寺山 星, 他：日本語版 Zurich claudication questionnaire (ZCQ) の開発一言語的妥当性を担保し た翻訳版の作成。整形外科 61:159-165，2010

16）鈴木 恒，馬見塚尚孝，芋生祥之，他：腰部脊柱管狭窄症患 者に対する日本語版チューリッヒ跛行質問票と 6 分間歩行試 験の試用評価と基準関連妥当性検証. 日脊椎脊髄病会誌 4:63-67, 2013

17）安田宗義：春髄外科研究に用いられるスコアリングシステム およびその特徵一頚椎疾患の評価システム。春髄外科 28 : 246-251, 2014

18) Pincus T, Burton AK, Vogel S, et al : A systematic review of psychological factors as predictors of chronicity/disability in prospective cohorts of low back pain. Spine 27 : E109-120, 2002

19) Urban-Baeza A, Zárate-Kalfópulos B, Romero-Vargas S, et al : Influence of depression symptoms on patient expectations and clinical outcomes in the surgical management of spinal stenosis. J Neurosurg Spine $22: 75-79,2015$

20) Yoshida K, Sekiguchi M, Otani K, et al : A validation study of the Brief Scale for Psychiatric problems in Orthopaedic Patients (BS-POP) for patients with chronic low back pain (verification of reliability, validity, and reproducibility).J Orthop Sci $\quad \mathbf{1 6}: 7-$ 13, 2011

21) DeVine J, Norvell DC, Ecker E, et al : Evaluating the correlation and responsiveness of patient-reported pain with function and quality-of-life outcomes after spine surgery. Spine $\mathbf{3 6}$ : S69-74, 2011

22) Yamashita K, Hayashi J, Ohzono K, et al : Correlation of patient satisfaction with symptom severity and walking ability after surgical treatment for degenerative lumbar spinal stenosis. Spine $28: 2477-2481,2003$

23) Copay AG, Martin MM, Subach BR, et al : Assessment of spine surgery outcomes : inconsistency of change amongst outcome measurements. Spine J 10 : 291-296, 2010

24) Gum JL, Glassman SD, Carreon LY : Clinically important deterioration in patients undergoing lumbar spine surgery $: \mathrm{a}$ choice of evaluation methods using the Oswestry Disability Index, 36-Item Short Form Health Survey, and pain scales : clinical article. J Neurosurg Spine 19 : 564-568, 2013 